\title{
TLR4 GENE EXPRESSION IN PATIENTS WITH CHRONIC SUPPURATIVE OTITIS MEDIA
}

\author{
J. T. VENKATARAVANAPPA ${ }^{1}$, K. C. PRASAD 2 , S. BALAKRISHNA ${ }^{1 凶}$ \\ ${ }^{1}$ Department of Cell Biology and Molecular Genetics, Sri Devaraj Urs Academy \\ of Higher Education and Research, Karnataka, India; \\ ${ }^{2}$ Department of Otorhinolaryngology, Sri Devaraj Urs Medical College, Sri Devaraj Urs \\ Academy of Higher Education and Research, Kolar-563103, Karnataka, India; \\ e-mail: sharath@sduu.ac.in
}

Received: 23 July 2021; Accepted: 12 November 2021

\begin{abstract}
Chronic suppurative otitis media (CSOM) is an infectious disease of the middle ear that involves inflammation and accumulation of fluid behind the eardrum. The pathogenesis of CSOM involves reduced bacterial clearance due to impairment of Toll-Like Receptor (TLR) 4 pathway. TLR4 receptor serves as the molecular sensor for bacterial endotoxin (lipopolysaccharide) and activates inflammatory cell signaling for clearing the bacteria. Previous studies have shown that the expression of TLR4 gene is reduced in middle ear epithelia of CSOM patients. Whether the expression of TLR4 gene is reduced in leukocytes is not known. In our present study we aim to compare the expression of the TLR4 gene in the blood samples of CSOM patients and healthy controls. A case-control study was carried out by involving 16 participants in each group. The levels of the TLR4 gene expression were measured by using the qRT-PCR method. The median (interquartile range) $\triangle C t$ values of the TLR4 gene expression was 4.85 (2.61-8.55) in the patient group and 2.29 (-1.63-4.85) in healthy controls. Expression of the TLR4 gene in the leukocytes of CSOM patient group was reduced by $\sim 5.9$ fold compared to the control group and the difference was found to be significant $(\mathrm{P}=0.01)$.
\end{abstract}

Keywords: chronic suppurative otitis media, gene expression, toll-like receptor 4 (TLR4).

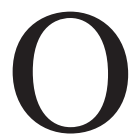

titis media $(\mathrm{OM})$ is a group of complex infectious and inflammatory disease that affects the middle ear cavity. OM can be classified into two subtypes as acute and chronic.acute form of OM (AOM) can lead to chronic suppurative OM (CSOM). Chronic suppurative OM (CSOM) involves persistent infection and continuous ottorrhea for more than 3 episodes in a month with a tympanic membrane perforation [1,2]. CSOM results in serious complications such as brain abscess, hearing loss, meningitis, and facial nerve paralysis [3]. The global estimate of prevalence rate ranges between 1-46\% of CSOM [4]. Pseudomonas aeruginosa (37.21\%) and Staphylococcus aureus (27.91\%) are the most common bacteria observed in the middle ear fluids of CSOM patients [5].

CSOM is considered to be a multifactorial disease with a genetic component. Animal studies have shown that the TLR4 gene is involved in the development of CSOM. The TLR4 gene codes for the type 1 transmembrane protein called Toll-Like Receptor 4 (TLR4) which functions as a pattern recognition receptor specifically for the lipopolysaccharide. The latter molecule is derived from the cell wall of gram-negative bacteria [6,7]. TLR4 is expressed in macrophages, monocytes, dendritic cells, and epithelial cells [8]. The binding of lipopolysaccharide to TLR4 receptor activates the intracellular cell signalling pathway which then results in the secretion of inflammatory cytokines. These cytokines then elicit a protective immune response against bacterial infection. Inactivation of the TLR4 gene is assumed to compromise the development of a protective immune response and lead to persistent infection [9].

Consistent with the above view, down-regulation of the TLR4 gene has been reported in the

(C) 2021 Venkataravanappa J. T. et al. This is an open-access article distributed under the terms of the Creative Commons Attribution License, which permits unrestricted use, distribution, and reproduction in any medium, provided the original author and source are credited. 
middle ear epithelia of CSOM patients [10]. It is not known if this pattern is unique to middle ear epithelia or shared by other cell types that express the TLR4 gene. This study was undertaken to answer this question. The aim of this study was to compare the expression of the TLR4 gene in the blood samples of CSOM patients and healthy controls.

\section{Materials and Methods}

Study design. The case-control design was used to conduct the study. The case group comprised of CSOM patients $(n=16)$ and the control group comprised of age and gender-matched healthy controls $(n=16)$. The study was approved (SDUAHER/KLR/ CEC/01/2017-18) by the Central Ethics Committee. Patients attending the Department of Otorhinolaryngology, R. L. Jalappa Hospital and Research Centre, Tamaka, Kolar, Karnataka, India, and the patients were enrolled between October 2018-August 2019.

Participant selection. CSOM was diagnosed based an otoscopic examination and the following criteria (i) perforation involving tympanic membrane (ii) chronic ear infection and (iii) hard of hearing. Inclusion criteria for the cases were (i) patients diagnosed with CSOM (ii) both genders in the age group of 18-60 years. Exclusion criteria for the CSOM patients were (i) acute otitis media without effusion, (ii) post-traumatic CSOM, (iii) cleft lip/ palate, (iv) down's syndrome, and (v) otomycosis [11]. The patient information sheet and written informed consent form were obtained prior to the recruitment of study subjects. One $\mathrm{ml}$ of whole blood samples of both CSOM patients and healthy controls were collected in an EDTA vacutainer and used for quantification of TLR4 gene expression.

Quantification of TLR4 gene expression by $q R T$ $P C R$. The TLR4 gene expression was performed by using quantitative reverse transcription polymerase chain reaction (qRT-PCR) CFX96 touch system (Bio-Rad, USA). Total RNA was isolated from $1 \mathrm{ml}$ blood samples of both cases $(n=16)$ and controls ( $n=16)$ using Trizol reagent (GeNei, Bangalore) based on protocol provided by the manufacturer's instruction [12]. The concentration and purity of the total RNA were measured using a spectrophotometer (PerkinElmer UV-VIS (Lambda 35), USA). RNA samples were stored at $-20^{\circ} \mathrm{C}$ until further use. The RNA samples of good quality (260/280 ratio of $>2)$ were used for conversion of cDNA. Total RNA samples were converted to cDNA using iScript cDNA conversion kit (Bio-Rad, USA). Real-time quantifi- cation of TLR4 and GAPDH genes were performed using SYBR green method (Bio-Rad, USA).

Following primers were used to quantify the expression of TLR4 and GAPDH (Sigma, USA):

TLR4 gene:

Forward primer: 5' GAACCTGGACCTGAGCTTTAAT 3'

Reverse primer: 5' GTCTGGATTTCACACCTGGATAA $3^{\prime}$

\section{GAPDH gene:}

Forward primer: 5' GATCATCAGCAATGCCTCCT-3',

Reverse primer: 5' GACTGTGGTCATGAGTCCTTC $3^{\prime}$

The composition of qRT-PCR reaction mixture is as follows: $2 \mu \mathrm{l}$ of cDNA (1:10 dilution), $0.5 \mu \mathrm{l}$ of forward and reverse primers, $5 \mu \mathrm{l}$ of SYBR green, and $2 \mu \mathrm{l}$ of nuclease-free water. The reaction conditions used for qRT-PCR were as follows: hold at $50^{\circ} \mathrm{C}$ for $2 \mathrm{~min}, 40$ cycles of hold at $95^{\circ} \mathrm{C}$ for $10 \mathrm{~min}$, denature at $95^{\circ} \mathrm{C}$ for $15 \mathrm{sec}$ and anneal/extension at $54.3^{\circ} \mathrm{C}$ for $60 \mathrm{sec}$. At the end of the reaction, the Cycle Threshold $(\mathrm{Ct})$ values were obtained from the analysis software. The expression of the TLR4 gene was normalized using GAPDH as endogenous control and the fold change in TLR4 gene expression was calculated using the $2^{-(\Delta \Delta C t)}$ method [13].

Statistical analysis. All the statistical analysis was carried out using SPSS Statistics V22.0 (IBM, USA); qualitative variables were represented by percentages. Differences between the two groups were compared by using non parametric test Mann -Whitney $U$ test. $P$-value less than 0.05 were considered to be statistically significant.

\section{Results}

The demographic and clinicalcharacteristics of the study participants were given in Table. The mean age of both CSOM patient and control groups was $31.75 \pm 9.89$ years. In both groups, $31.25 \%$ of the participants were male and $68.75 \%$ were female. Majority of the patients showed bilateral involvement of CSOM (68.75\%). The common site of tympanic perforation was central (68.75\%) followed by posterior (18.75\%), and anterior locations (12.05\%). Cholesteatoma formation was observed only in few patients (12.50\%).

The TLR4 gene expression was quantified by using qRT-PCR. The resulting $\Delta \mathrm{Ct}$ values did not show normal distribution. Therefore, median and interquartile range (IQR) was calculated for both 
the groups. The median $\triangle \mathrm{Ct}$ of TLR4 gene was 4.85 (2.61 to 8.55) in CSOM group and 2.29 (-1.63 to $4.85)$ in control group. The difference between the median $\Delta \mathrm{Ct}$ values of the CSOM and control groups was statistically significant ( $P=0.01$; Mann-Whitney $U$ test). The results were represented graphically in Fig. 1. Comparative Ct method used to calculate the fold change in TLR4 gene expression. The average TLR4 gene expression in the CSOM group was found to be 0.17 compared to the control group. Thus, the gene expression in the CSOM group was about 5.9 times lower than in the control group.

Further, the TLR4 gene expression data was analysed after subgrouping the CSOM patients based on the clinical profile. Significant difference was observed between unilateral and bilateral subgroups ( $P=0.03$; Mann-Whitney $\mathrm{U}$ test). The results are shown in Fig. 2. Downregulation of the TLR4 gene expression was severe in the bilateral subgroup than in the unilateral subgroup. There was no significant difference between patients with and without cholesteatoma $(P=0.26$; Mann-Whitney U test).

\section{Discussion}

The purpose of this study was to compare the TLR4 gene expression in CSOM patients and healthy controls. The results of this study show that the levels of TLR4 gene expression are reduced in CSOM patients compared to healthy controls. This implies that the TLR4 gene expression is down-regulated in CSOM. To the best of our knowledge, this is the first study to quantify the TLR4 gene expression in the blood samples of CSOM patients.

The results of this study are in agreement with the pattern reported in the middle mucosa of CSOM patients. Si and co-workers reported that expression

Ta b le. Demographic and clinical parameters of study participants

\begin{tabular}{|c|c|c|}
\hline Parameter & CSOM patients $(n=16)$ & Controls $(n=16)$ \\
\hline Age (Years) (mean \pm SD) & $31.75 \pm 9.89$ & $31.75 \pm 9.89$ \\
\hline \multicolumn{3}{|l|}{ Gender } \\
\hline Male & 05 (31.25\%) & 05 (31.25\%) \\
\hline Female & $11(68.75 \%)$ & $11(68.75 \%)$ \\
\hline \multicolumn{3}{|l|}{ Ear affected } \\
\hline Unilateral & 05 (31.25\%) & NA \\
\hline Bilateral & 11 (68.75\%) & NA \\
\hline \multicolumn{3}{|l|}{ Perforated TM } \\
\hline Anterior & 02 (12.05\%) & NA \\
\hline Central & 11 (68.75\%) & NA \\
\hline Posterior & 03 (18.75\%) & NA \\
\hline \multicolumn{3}{|l|}{ Disease duration } \\
\hline$\leq 1$ year & 06 (37.50\%) & NA \\
\hline$>1$ year to $\leq 5$ years & 06 (37.50\%) & NA \\
\hline$>5$ year to $\leq 10$ years & 03 (18.75\%) & NA \\
\hline Since childhood & 01 (06.25\%) & NA \\
\hline \multicolumn{3}{|l|}{ CSOM } \\
\hline With Cholesteatoma & 02 (12.50\%) & NA \\
\hline Without Cholesteatoma & $14(87.50 \%)$ & NA \\
\hline \multicolumn{3}{|l|}{ Presenting symptoms } \\
\hline Ear discharge & 13 (81.25\%) & NA \\
\hline Hearing loss & 09 (56.25\%) & NA \\
\hline Ear ache & 16 (100.00\%) & NA \\
\hline
\end{tabular}

CSOM - Chronic Suppurative Otitis Media; SD - Standard Deviation; NA - Not Applicable; TM - Tympanic membrane 


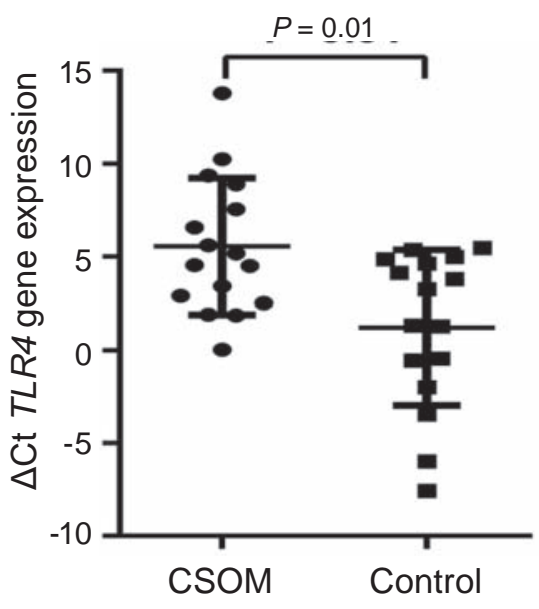

Fig. 1. Differential expression ( $\triangle C t$ values) of TLR4 gene in CSOM group vs. controls. Median $\Delta C t_{\text {Csom }}=4.85$; relative gene expression $=0.17$; Median $\Delta C t_{\text {Controls }}=2.29$; relative gene expression $=1.00$

of the TLR4 gene is lower in middle ear mucosal samples of CSOM patients compared to that of controls [14]. The TLR4 gene expression levels were not altered in children with a history of OM compared to control in middle ear tissue samples [15]. Also, the TLR4 gene expression is downregulated in middle ear tissue samples of CSOM patients in comparison to controls [16]. Together these report suggest that $T L R 4$ gene expression were downregulated in OM.

The role of the TLR4 gene in the pathogenesis of otitis media has been established with animal studies. Two mice strains (C3H/HeJ and C57BL/6) with knock out of the TLR4 gene have been developed. Carol and co-workers evaluated the visual changes in the tympanic membrane and auditory brainstem response in 7-8-month-old C3H/HeJ mice. The authors found that the $\mathrm{C} 3 \mathrm{H} / \mathrm{HeJ}$ mice developed OM spontaneously. Furthermore, increased hearing loss of mixed type and also inflammation in the middle ear were found [17]. Leichtle and coworkers evaluated the C57BL/6 mice and noticed an increase in the middle ear mucosal thickness, cel-

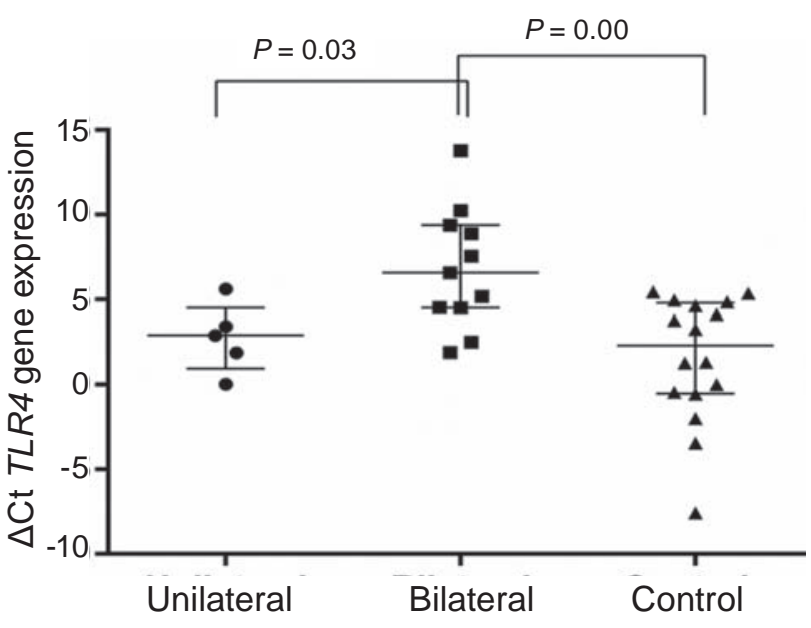

Fig. 2. Differential expression ( $\triangle C t$ values) of TLR4 gene in bilateral CSOM group, unilateral CSOM group and controls. Median $\Delta C t_{\text {Bilateral }}=6.57$; relative gene expression $=0.05$, Median $\Delta C t_{\text {Unilatreal }}=2.90$; relative gene expression $=0.65$ ); Median $\Delta C t_{\text {Controls }}=2.29$; relative gene expression $=1.00$

lular infiltration in the middle ear cavity. In addition, they reported that the bacterial clearance in the middle ear cavity was reduced [18]. These reports indicate that genetic variations are the likely cause for the impairment of Toll-Like Receptor 4 in OM. This view is supported by several genetic assocation studies [19-21].

Conclusion. The present study shows that the $T L R 4$ gene expression is downregulated in the leucocytes of CSOM patients.

Conflict of interest. Authors have completed the Unified Conflicts of Interest form at http://ukrbiochemjournal.org/wp-content/uploads/2018/12/ coi disclosure.pdf and declare no conflict of interest.

Acknowledgments. Thanks to Nagarjuna Reddy MSc student, Sri Devraj Urs Academy of Higher Education and Research for his help in collection of sample. 


\section{ЕКСПРЕСІЯ ГЕНА TLR4 У \\ ПАЦІЕНТІВ ІЗ ХРОНІЧНИМ ГНІЙНИМ СЕРЕДНІМ ОТИТОМ}

\author{
J. T. Venkataravanappa ${ }^{1}$, K. C. Prasad ${ }^{2}$, \\ S. Balakrishna ${ }^{1 \bowtie}$
}

${ }^{1}$ Department of Cell Biology and Molecular Genetics, Sri Devaraj Urs Academy of Higher Education and Research, Karnataka, India; ${ }^{2}$ Department of Otorhinolaryngology, Sri Devaraj Urs Medical College, Sri Devaraj Urs Academy of Higher Education and Research, Karnataka, India; 凶e-mail: sharath@sduu.ac.in

Хронічний гнійний середній отит (ХГСО) інфекційне захворювання середнього вуха, яке супроводжується запаленням та скупченням рідини за барабанною перетинкою. Патогенез ХГСО характеризується зниженням бактеріального кліренсу через порушення сигнального шляху рецептора TLR4, який $\epsilon$ молекулярним сенсором бактеріального ендотоксину (ліпополісахариду) i активатором протизапальної сигнальної системи клітин для знищення бактерій. Попередні дослідження показали, що експресія гена TLR4 знижена в епітелії середнього вуха пацієнтів із ХГСО. Чи знижена експресія гена TLR4 у лейкоцитах, невідомо. Метою дослідження було порівняти експресію генів $T L R 4$ у зразках крові пацієнтів із ХГCО та здорових осіб за допомогою кількісної ПЛР. Проведено дослідження “випадок-контроль" за участю 16 осіб у кожній групі. Медіана (міжквартильний розмах) значення $\Delta \mathrm{Ct}$ експресії гена TLR4 склала $4,85(2,61-8,55)$ у групі пацієнтів із ХГСО та $2,29(-1,63-4,85)$ у групі здорових осіб. Експресія гена TLR4 у лейкоцитах пацієнтів із ХГСО була знижена в $\sim 5,9$ раза у порівнянні з контрольною групою, і ця різниця виявилася статистично значущою $(P=0,01)$.

К л юч ов і слова: хронічний гнійний середній отит, експресія генів, рецептор TLR4.

\section{References}

1. Mittal R, Lisi CV, Gerring R, Mittal J, Mathee K, Narasimhan G, Azad RK, Yao Q, Grati M, Yan D, Eshraghi AA, Angeli SI, Telischi FF, Liu XZ. Current concepts in the pathogenesis and treatment of chronic suppurative otitis media. J Med Microbiol. 2015; 64(10): 1103-1116.
2. Bhutta MF, Thornton RB, Kirkham LAS, Kerschner JE, Cheeseman MT. Understanding the aetiology and resolution of chronic otitis media from animal and human studies. Dis Model Mech. 2017; 10(11): 1289-1300.

3. Hutz MJ, Moore DM, Hotaling AJ. Neurological Complications of Acute and Chronic Otitis Media. Curr Neurol Neurosci Rep. 2018; 18(3): 11.

4. Muftah S, Mackenzie I, Faragher B, Brabin B. Prevalence of Chronic Suppurative Otitis Media (CSOM) and Associated Hearing Impairment Among School-aged Children in Yemen. Oman Med J. 2015; 30(5): 358-365.

5. Balan S, Viswanatha B. Microbiology of Chronic Suppurative Otitis Media: A Prospective Study in a Tertiary Care Hospital. J Otolaryngol ENT Res. 2017; 9(1): 00277.

6. Nie L, Cai SY, Shao JZ, Chen J. Toll-Like Receptors, Associated Biological Roles, and Signaling Networks in Non-Mammals. Front Immunol. 2018; 9: 1523.

7. Molteni M, Gemma S, Rossetti C. The Role of Toll-Like Receptor 4 in Infectious and Noninfectious Inflammation. Mediators Inflamm. 2016; 2016: 6978936.

8. Zmonarski SC, Banasik M, Madziarska K, Mazanowska O, Krajewska M. The role of tolllike receptors in multifactorial mechanisms of early and late renal allotransplant injury, with a focus on the TLR4 receptor and mononuclear cells. Adv Clin Exp Med. 2019; 28(7): 981-987.

9. Zhang J, Xu M, Zheng Q, Zhang Y, Ma W, Zhang Z. Blocking macrophage migration inhibitory factor activity alleviates mouse acute otitis media in vivo. Immunol Lett. 2014; 162(1 Pt A): 101-108.

10. Granath A, Cardell LO, Uddman R, Harder H. Altered Toll- and Nod-like receptor expression in human middle ear mucosa from patients with chronic middle ear disease. $J$ Infect. 2011; 63(2): 174-176.

11. Harmes KM, Blackwood RA, Burrows HL, Cooke JM, Harrison RV, Passamani PP. Otitis media: diagnosis and treatment. Am Fam Physician. 2013; 88(7): 435-440.

12. Chomczynski P. A reagent for the singlestep simultaneous isolation of RNA, DNA and proteins from cell and tissue samples. Biotechniques. 1993; 15(3): 532-534, 536-537. 
13. Livak KJ, Schmittgen TD. Analysis of relative gene expression data using real-time quantitative PCR and the 2(-Delta Delta C(T)) Method. Methods. 2001; 25(4): 402-408.

14. Si Y, Zhang ZG, Chen SJ, Zheng YQ, Chen YB, Liu Y, Jiang H, Feng LQ, Huang X. Attenuated TLRs in middle ear mucosa contributes to susceptibility of chronic suppurative otitis media. Hum Immunol. 2014; 75(8): 771-776.

15. Granath A, Uddman R, Cardell LO. Increased TLR7 expression in the adenoids among children with otitis media with effusion. Acta Otolaryngol. 2010; 130(1): 57-61.

16. Tuoheti A, Gu X, Cheng X, Zhang H. Silencing Nrf2 attenuates chronic suppurative otitis media by inhibiting pro-inflammatory cytokine secretion through up-regulating TLR4. Innate Immun. 2021; 27(1): 70-80.

17. MacArthur CJ, Hefeneider SH, Kempton JB, Trune DR. C3H/HeJ mouse model for spontaneous chronic otitis media. Laryngoscope. 2006; 116(7): 1071-1079.

18. Leichtle A, Hernandez M, Pak K, Yamasaki K, Cheng CF, Webster NJ, Ryan AF, Wasserman SI. TLR4-mediated induction of TLR2 signaling is critical in the pathogenesis and resolution of otitis media. Innate Immun. 2009; 15(4): 205215.

19. Emonts M, Veenhoven RH, Wiertsema SP, Houwing-Duistermaat JJ, Walraven V, de Groot R, Hermans PWM, Sanders EAM. Genetic polymorphisms in immunoresponse genes TNFA, IL6, IL10, and TLR4 are associated with recurrent acute otitis media. Pediatrics. 2007; 120(4): 814-823.

20. Hafrén L, Einarsdottir E, Kentala E, HammarénMalmi S, Bhutta MF, MacArthur CJ, Wilmot B, Casselbrant M, Conley YP, Weeks DE, Mandel EM, Vaarala O, Kallio A, Melin M, Nieminen JK, Leinonen E, Kere J, Mattila PS. Predisposition to Childhood Otitis Media and Genetic Polymorphisms within the Toll-Like Receptor 4 (TLR4) Locus. PLoS One. 2015; 10(7): e0132551.

21. Alpay HC, Etem EO, Kaygusuz I, Yüce H, Karlidag T, Keles E, Orhan I, Yalcin S. Evaluation of the polymorphism in the Toll-like receptor 4 (TLR4) genes of tympanosclerosis patients. Auris Nasus Larynx. 2010; 37(1): 29-32. 